\title{
legelivet
}

På disse sidene i Tidsskriftet - legelivet - finner du stoff om legers liv.

Her er det presentasjon av arbeidssteder, nyhetssaker, nye doktorgrader,

nye spesialister og minneord. Alt samlet på ett sted - så du kan følge enda bedre med.

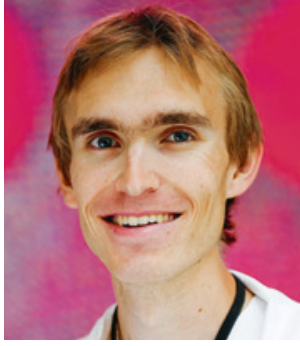

Frederik Emil Juul. Foto: Jon Olav Nesvold

Frederik Emil Juul (f. 1989) er turnuslege ved Sykehuset Innlandet, Hamar.

\section{Like leger lunsjer best?}

\author{
«Mitt første råd til deg som skal i turnus, er å vente med å finne deg \\ en plass på morgenmøtet til alle andre har satt seg.»
}

Uttalelsen kom fra en svært erfaren lege da jeg diskuterte min egen kommende turnustjeneste. Selv om han sa det med et glimt i øyet, tror jeg det fremdeles er en viss sannhet i det han sa. For fortsatt er det hierarkisk plassfordeling ved møte- og lunsjbord på enkelte sykehus og legekontorer - og der må man for all del sette seg på den rette stolen. Det er i hvert fall erfaringen til flere nyutdannede leger, inkludert meg selv.

Samtidig er det mange sykehus og legekontorer med mer avslappede forhold og her kan man sette seg der det er plass. Særlig i matpausene opplever jeg dette som fint, og Elisabeth Swensen uttrykte samme mening i Legelivet tidligere i år (1).

Selvsagt kan det være trivielle årsaker til at lunsjen tilbringes i segregerte (fag)grupper. For eksempel at pauserommet - om det finnes noe eget rom - er for lite til at mer enn en håndfull leger eller sykepleiere kan samles der. Dessuten ville det vært problematisk på et sykehus om samtlige ansatte slapp det de hadde i hendene klokken halv tolv for så å bli borte den neste halvtimen grunnet lunsjpausen. En annen grunn til atskilte lunsjgrupper kan være den felles erfaringen og livssituasjonen ulike yrkesgrupper ofte har, med mer eller mindre tilsvarende utdanning og arbeidserfaring.
Likevel er jeg av den oppfatning at stemningen er best der strukturen er flatest. Der psykologer, sykepleiere, sosionomer og leger i ulike stillinger og av ulik rang sitter ved samme bord. Lunsjpausen trenger ikke være en demonstrasjon i hvem som er leder for avdelingen, legene eller teamet. I tillegg til samtaletemaer av sosial art, som hvor man liker å tilbringe påskeferien, kan det komme faglige innspill og endringsønsker fra egen og andre yrkesgrupper, ideer som kanskje ikke ville kommet frem i en mer formell gjennomgang av avdelingens rutiner og arbeidshverdag.

Som fersk turnuslege håper jeg å kunne dele opplevelser og erfaringer med ulike kolleger ved lunsjbordet - alt fra overlegens hytteanbefaling i Rondane til sykepleiernes frustrasjon over feilutfylte legemiddelkurver. Interesser og ønsker er ofte likere enn yrkesbakgrunnen skulle tilsi.

Frederik Emil Juul

fejuul.medisin@gmail.com

Litteratur

1. Swensen E. En åpen dør. Tidsskr Nor Legeforen 2016: 136: 154 